\title{
ANALISIS PENENTUAN DAYA DAN TEMPERATUR KONDISI TUNAK PADA PENGUJIAN KONSUMSI ENERGI LEMARI PENDINGIN BERDASARKAN IEC 62552:2015
}

\section{Determination Analysis of Steady-State Power and Temperature in Testing of Refrigerator Energy Consumption Based on IEC 62552:2015}

\author{
Nanang Kusnandar, Prayoga Bakti, Iput Kasiyanto, Qudsiyyatul Lailiyah \\ Pusat Penelitian Sistem Mutu dan Teknologi Pengujian - LIPI \\ Gedung 417, Jalan Kawasan Puspiptek, Serpong, Tangerang, banten, Indonesia \\ e-mail: nkusnandar@yahoo.com
}

Diterima: 6 Agustus 2018, Direvisi: 13 November 2018, Disetujui: 15 November 2018

\begin{abstract}
Abstrak
Perhitungan konsumsi energi suatu piranti kelistrikan rumah tangga diperlukan sebagai dasar penentuan taraf/level bintang untuk labelisasi energi produk tersebut. Pada produk lemari pendingin (kulkas), perhitungan konsumsi energi dilakukan pada saat daya dan temperatur sudah mencapai kondisi tunak (steady state). Berdasarkan IEC 62552:2015, terdapat dua pendekatan untuk menentukan kondisi tunak, yaitu pendekatan SS1 dan SS2. Makalah ini mengkaji perbandingan hasil antara kedua pendekatan tersebut dengan menggunakan data pengukuran daya dan temperatur dari suatu lemari pendingin dua pintu. Metode pengujian dan pengukuran dilakukan dengan mengacu kepada standar IEC 62552-1:2015 dan IEC 62552-3:2015. Hasil kajian menunjukkan bahwa daya dan temperatur kondisi tunak yang didapatkan dengan menggunakan pendekatan SS1 tidak berbeda jauh dengan yang menggunakan pendekatan SS2.
\end{abstract}

Kata kunci: konsumsi energi, lemari pendingin, IEC 62552:2015, pendekatan SS1, pendekatan SS2

\section{Abstract}

The calculation of energy consumption of a household electrical appliance is required as a basis for determining the star level for the energy labeling of the product. For refrigerator product, the energy consumption is calculated when power and temperature have reached steady state. Based on IEC 62552: 2015, there are two possible cases with respect to determination of steady state conditions, namely Case SS1 and Case SS2 approaches. This paper examined the comparison of results between the two cases using the measurement data of power and temperature of a two-door refrigerator. Testing and measurement methods were carried out refer to IEC 62552-1: 2015 and IEC 62552-3: 2015 standard. The results showed that the steady-state power and temperature obtained using case SS1 were not much different from those using case SS2.

Keyword: energy consumption, refrigerator, IEC 62552:2015, case SS1, case SS2

\section{PENDAHULUAN}

Penerapan standar efisiensi energi dan program labelisasi energi untuk produk kelistrikan rumah tangga merupakan salah satu strategi yang paling populer digunakan oleh pemerintah di banyak negara. Kebijakan ini dipandang cukup efektif dalam menghemat penggunaan energi dan memberikan edukasi terhadap konsumen (masyarakat) untuk menggunakan energi secara bijaksana (Mahlia \& Saidur, 2010). Pada prakteknya, kebijakan ini akan menerapkan nilai minimum energy performance standard (MEPS) atau standar kinerja energi minimum (SKEM) untuk setiap produk, sehingga bisa meningkatkan efisiensi energi produk di pasaran karena dengan sendirinya produk-produk yang tidak memenuhi MEPS akan tereliminasi dan hanya produkproduk yang lebih efisien sajalah yang mampu bertahan (Chunekar, 2014). Di Amerika Serikat, penegakan standar efisiensi energi minimum dinilai mampu berkontribusi pada pengurangan yang signifikan dalam permintaan listrik sektor perumahan dan komersial, serta berpotensi untuk mengurangi jumlah pembangkit listrik baru (Bansal dkk, 2011).

Di Indonesia, peneraan label energi untuk piranti rumah tangga telah diatur dalam SNI 046958-2003. Selain itu, beberapa standar kinerja produk juga sudah dikeluarkan oleh BSN dan menjadi dasar dalam penentuan konsumsi energi produk-produk tersebut, antara lain: SNI IEC 
60969:2009 (lampu swabalast), SNI ISO 5151:2015 (pengkondisi udara/AC), SNI ISO 15502:2009 (kulkas), SNI IEC 60879:2013 (kipas angin), SNI IEC 60311:2009 (setrika), dan SNI IEC 60456:2009 (mesin cuci). Namun dalam pelaksanaannya, sampai saat ini baru dua produk yang dinyatakan wajib untuk menerakan label tanda hemat energi tersebut, yakni lampu swabalast dan AC. Sedangkan produk-produk lainnya masih dalam tahap pembahasan dan persiapan.

Jika dilihat dari skala prioritas, lemari pendingin (kulkas) termasuk produk yang cukup mendesak untuk diterapkan kebijakan labelisasi tersebut. Hal ini disebabkan lemari pendingin termasuk penyumbang pemakai energi listrik yang paling besar di rumah tangga, terutama untuk golongan tarif R1-450VA, R1-900VA dan R1-1300VA (BPPT, 2012), bahkan secara umum diperkirakan mencapai $10 \%$ dari total energi listrik yang diproduksi di seluruh dunia (Melo \& Silva, 2010) serta menyebabkan emisi gas rumah kaca tahunan sebesar 450 juta ton $\mathrm{CO}_{2 \text { eq }}$ (Ouali dkk, 2016). Besarnya kontribusi ini dikarenakan lemari pendingin merupakan piranti yang sudah umum digunakan di dalam rumah tangga dan dalam pemakaiannya terus terhubung dengan sumber daya (Geppert, 2013). Selain itu, piranti inipun dilaporkan memiliki efisiensi termodinamika yang rendah, dengan nilai yang tidak lebih tinggi dari $20 \%$ (COP Actual / COP Carnot) (Hermes \& Melo, 2008). Oleh karena itu, peningkatan kinerja yang relatif kecil pun pada produk lemari pendingin, jika dikalkulasi secara total dapat membawa penghematan energi dalam jumlah besar dan mengurangi emisi gas rumah kaca (Cheng dkk, 2017).

Perhitungan nilai konsumsi energi merupakan tahapan penting dalam menentukan nilai MEPS suatu produk, termasuk dalam hal ini lemari pendingin. Metode untuk menghitung konsumsi energi tersebut telah dijelaskan dalam standar kinerja lemari pendingin, yakni SNI ISO 15502:2009. Namun, secara internasional standar ini sebenarnya sudah digantikan oleh standar baru yaitu IEC 62552:2015. Terdapat perbedaan yang cukup signifikan antara kedua standar tersebut, terutama dalam metode pengujian dan perhitungan konsumsi energinya.

Kajian tentang pengujian dan perhitungan konsumsi energi lemari pendingin berdasarkan standar baru (yang waktu itu masih berupa draft standar) sudah pernah dilakukan oleh Dwi dan Nanang (2014). Hasilnya antara lain menyatakan bahwa penentuan kondisi tunak (steady state) pada saat pengujian perlu dilakukan dengan tepat dan akurat karena akan berpengaruh terhadap penetapan konsumsi energi secara keseluruhan. Dalam standar IEC 62552:2015 sendiri terdapat dua metode untuk menentukan kondisi tunak, yakni metode SS1 dan SS2. Seberapa jauh perbedaan hasil yang diperoleh ketika kedua metode ini digunakan merupakan hal yang menarik untuk dikaji lebih lanjut.

Penelitian yang disajikan dalam makalah ini dilakukan dengan tujuan untuk membandingkan hasil pengujian/perhitungan daya dan temperatur lemari pendingin menggunakan dua metode penentuan kondisi tunak berdasarkan standar IEC 62552:2015, yakni SS1 dan SS2. Hasilnya diharapkan bisa menjadi acuan bagi laboratorium uji dalam memilih metode mana yang akan dipakai pada saat melakukan pengujian.

\section{TINJAUAN PUSTAKA}

IEC 62552-3:2015 bagian Annex B menjelaskan bahwa ada dua metode penentuan kondisi tunak lemari pendingin pada saat pengujian, yakni pendekatan SS1 dan SS2. Proses perhitungan selanjutnya, baik untuk daya, temperatur, maupun energi dilakukan terhadap data yang termasuk dalam periode kondisi tunak tersebut.

\subsection{Pendekatan Kasus SS1}

Pada saat menentukan kondisi tunak menggunakan pendekatan SS1, suatu periode uji kondisi tunak yang terdiri dari 3 buah blok data uji harus dipilih. Ke-3 blok data uji tersebut harus berdekatan tapi tidak overlap. Masing-masing blok data uji terdiri beberapa temperature control cycle (TCC) dengan jumlah yang sama (n). Jumlah minimum TCC per blok adalah 1. Periode uji terpilih ini harus memenuhi kriteria yang ditetapkan berkaitan dengan sebaran dan slope suhu maupun daya.

Definisi TCC berdasarkan IEC 625521:2015 adalah ayunan (ritme) berulang definitif dari suhu yang disebabkan karena pengoperasian suatu perangkat kendali suhu (onoff atau lainnya). Periode 1 TCC adalah waktu antara suatu kejadian kontrol sampai terjadi pengulangannya pada siklus berikutnya. Kejadian kontrol sendiri adalah perubahan dalam kondisi operasi yang bisa berupa:

a) Mulai, berhenti, atau perubahan kecepatan kompresor;

b) Perubahan posisi baffle, operasi kipas, atau perangkat/kontrol modulasi lainnya;

c) Perubahan operasi sirkit refrigerant;

d) On/off pemanas (heater) defrost;

e) Operasi icemaker.

Apabila kejadian kontrol tidak dapat dibedakan, maka periode 1 TCC adalah waktu antara dua titik suhu terhangat yang berurutan atau antara dua titik terdingin yang berurutan.

Apabila perubahan temperatur atau konsumsi daya tidak terlihat dengan jelas, suatu periode uji yang terdiri dari 3 blok data uji bisa dipilih dengan syarat masing-masing blok 
(Nanang Kusnandar, Prayoga Bakti, Iput Kasiyanto, Qudsiyyatul Lailiyah)

meminkı durası waktu (panjang) yang sama, 3. Kemirıngan/slope sunu (darı blok A sampal C) berdekatan dan tidak kurang dari 4 jam lamanya. Suatu periode uji harus terdiri dari 3 blok data, disebut dengan blok $A, B$ dan $C$. Tidak ada batasan maksimum jumlah TCC per blok, namun biasanya jumlah 10 TCC sudah dianggap cukup panjang. Suatu contoh periode uji yang terdiri dari 5 TCC per blok diilustrasikan pada Gambar 1.

Untuk masing-masing blok data, dihitung rata-rata daya $\left(\mathrm{P}_{\mathrm{A}}, \mathrm{P}_{\mathrm{B}}\right.$ dan $\left.\mathrm{P}_{\mathrm{C}}\right)$ dan rata-rata suhu $\left(T_{A}, \quad T_{B}\right.$, dan $\left.T_{C}\right)$ pada masing-masing kompartemen. Selanjutnya dilakukan pemeriksaan validitas keseluruhan periode uji menurut kriteria keberterimaan kasus SS1. Suatu periode uji dikatakan valid apabila memenuhi semua kriteria SS1 berikut:

1. Total waktu blok $A, B$, dan $C$ tidak kurang dari 6 jam jika terjadi TCC dan tidak kurang dari 12 jam bila tidak terjadi TCC.

2. Sebaran nilai suhu (sepanjang blok $A, B, C$ ) tidak melebihi $0,25 \mathrm{~K}$ untuk setiap kompartemen, dengan nilai sebaran dihitung berdasarkan rumus:

tidak lebih dari $0,025 \mathrm{~K} / \mathrm{jam}$ untuk setiap kompartemen, dengan rumus kemiringan:

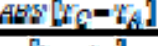 \\ $x g=x_{n}$}

(2)

4. Sebaran nilai daya (sepanjang blok $A, B, C$ ) dimana terjadi TCC, untuk waktu $t_{A B C}$ kurang dari 12 jam, adalah $\leq 1 \%$, untuk total waktu uji antara (12 sampai 36) jam tidak melebihi $1 \%+\left(t_{A B C}-12\right) / 1200$, dan untuk total waktu uji sama dengan atau lebih dari 36 jam, maka harus tidak lebih dari $3 \%$. Sebaran daya dihitung dengan rumus:

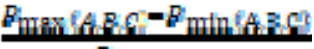 $B_{\text {GI }} A B$ ?}

5. Sebaran nilai daya (sepanjang blok $A, B, C$ ) tidak melebihi $1 \%$ bila tidak terjadi TCC/periode uji tetap.

6. Kemiringan daya (dari blok A sampai $\mathrm{C}$ ) lebih kecil dari $0,25 \% / j a m$ yang dihitung dengan rumus:

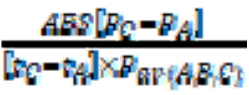

(4)

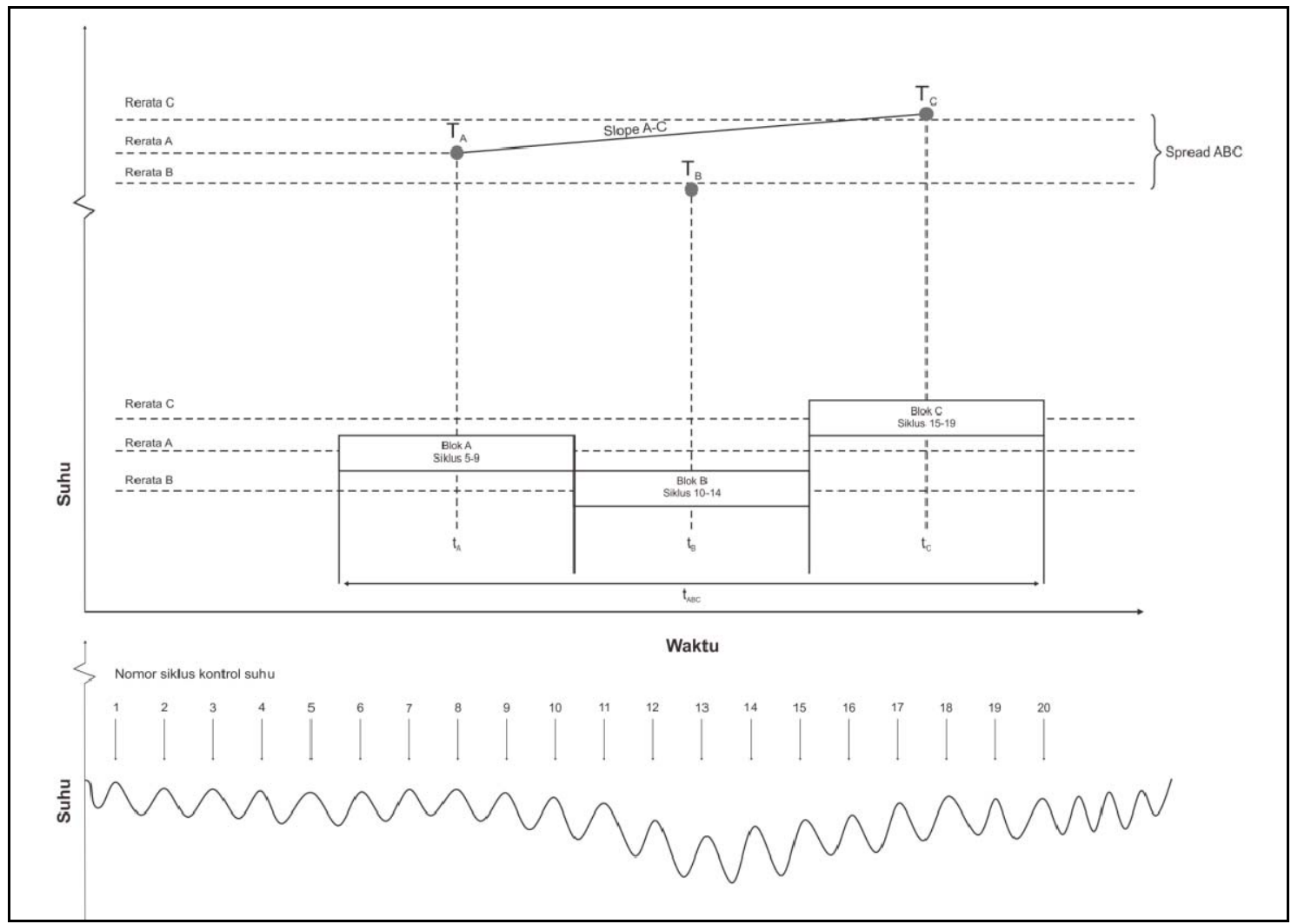

Gambar 1 llustrasi satu periode uji yang terdiri dari 3 blok data (1 blok = 5 TCC).

7. Jika terdapat TCC, dua periode uji yang dimulai dari satu dan dua TCC lebih awal dari periode uji terpilih juga harus memenuhi semua kriteria di atas. (Jadi, periode uji terpilih adalah periode ketiga yang mungkin dan memenuhi semua kriteria validitas di atas) 
8. Jika tidak terdapat TCC, dua periode uji yang dimulai dari satu dan dua jam lebih awal dari periode uji terpilih juga harus memenuhi semua kriteria di atas.

Daya rata-rata (Pss1) dan suhu rata-rata masing-masing kompartemen $\left(\mathrm{T}_{i}\right)$ dihitung dengan merata-ratakan semua nilai terukur selama periode waktu yang tercakup oleh blok $A$, B dan C.

\subsection{Pendekatan Kasus SS2}

Pendekatan SS2 menggunakan semua data diantara permulaan dua periode defrost dan recovery untuk menghitung daya kondisi stabilnya. Pemeriksaan dilakukan dengan membandingkan karakteristik operasi kondisi stabil sebelum masing-masing periode defrost dan recovery (disebut Periode $X$ dan Periode $Y$ dalam Gambar 2) untuk menjamin terpenuhinya kondisi kestabilan yang disyaratkan.Ujung dari Periode $X$ ialah pada saat dimulainya suatu periode defrost dan recovery, sedangkan ujung dari Periode $\mathrm{Y}$ ialah pada saat dimulainya periode defrost dan recovery berikutnya.

Suatu periode uji kondisi tunak dikatakan valid apabila memenuhi semua kriteria SS2 berikut:
1. Periode $X$ dan Periode $Y$ harus memiliki jumlah TCC yang sama (sedikitnya 4 TCC) dan panjang waktu yang relatif sama juga (minimal 4 jam). Apabila tidak terdapat TCC, maka panjang waktu kedua periode ini harus persis sama.

2. Jika menggunakan jumlah TCC, rasio panjang Periode $X$ (dalam jam) terhadap panjang periode $Y$ (dalam jam) harus berada diantara 0,8 sampai dengan 1,25 .

3. Sebaran temperatur diantara dua Periode $X$ dan Periode $Y$ terpilih harus kurang dari 0,5 $\mathrm{K}$ untuk masing-masing kompartemen, dengan rumus sebaran temperatur:

$T_{\max }(\mathrm{XX})-T_{\min }(\mathrm{X})$

4. Sebaran daya diantara dua Periode $X$ dan Periode $Y$ terpilih harus kurang dari $2 \%$ atau kurang dari $1 \mathrm{~W}$ (dipilih nilai mana yang lebih besar). Rumus sebaran daya:

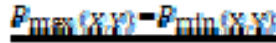

$$
B_{\text {aring }} \text {, dalam \% }
$$

atau,

$$
B_{\max (X X)}-B_{\min (X F)} \text {, dalam W }
$$

Setelah periode kondisi tunak terpilih, daya rata-rata (Pss2) dihitung dengan rumus:

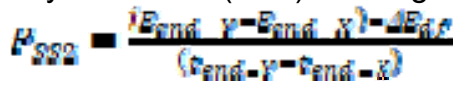

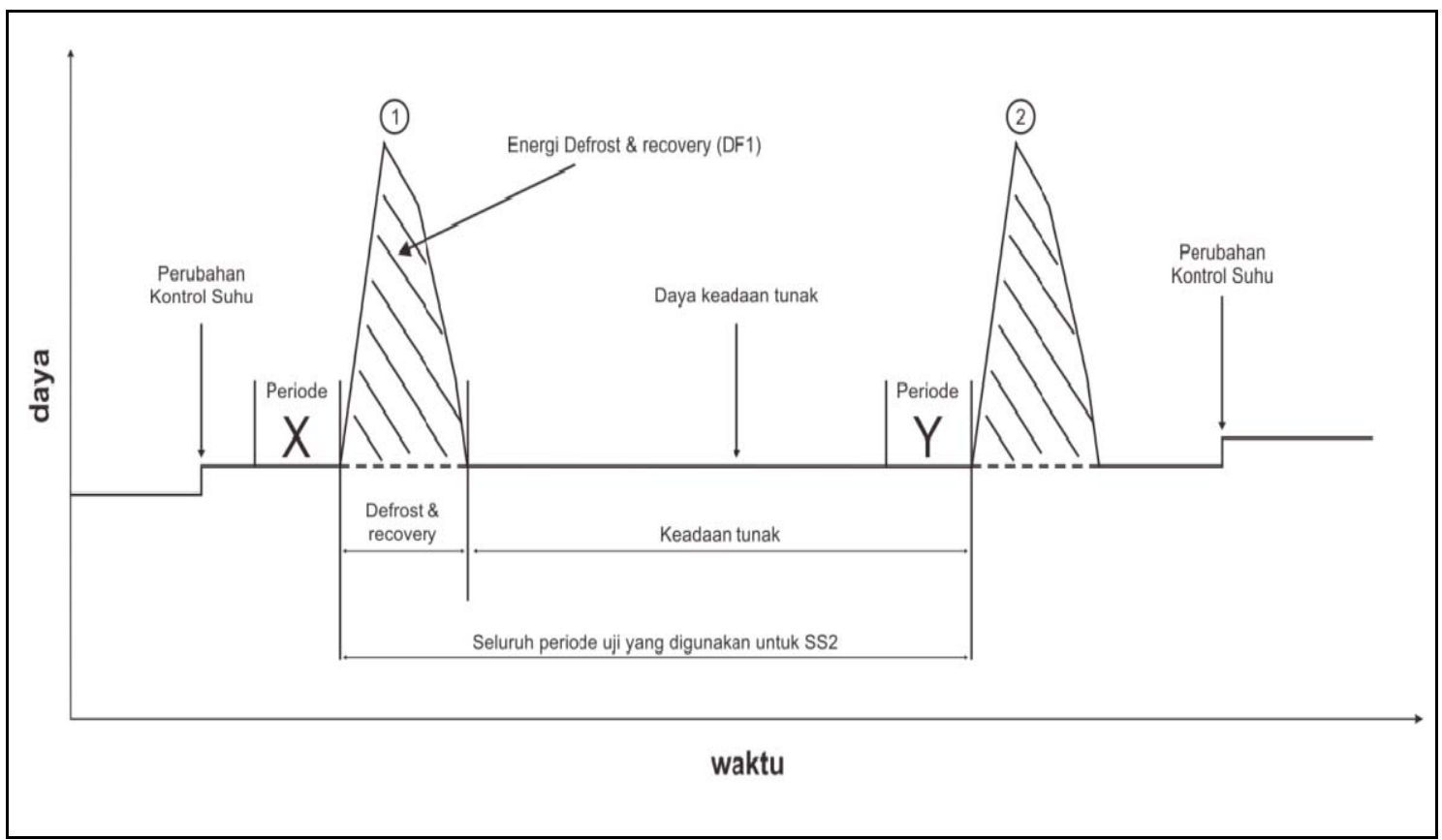

Gambar 2 Jenis operasi kondisi tunak pada pendekatan SS2.
Eend-X adalah energi akumulasi pada akhir $E_{\text {end-Y }}$ adalah energi akumulasi pada akhir Periode X (Wh)


Analisis Penentuan Daya dan Temperatur Kondisi Tunak Pada Pengujian Konsumsi Energi Lemari Pendingin Berdasarkan IEC 62552:2015

(Nanang Kusnandar, Prayoga Bakti, Iput Kasiyanto, Qudsiyyatul Lailiyah)

tend-X adalah waktu uji pada akhir Periode $X$ (jam)

tend-Y adalah waktu uji pada akhir Periode $Y$ (jam)

$\Delta \mathrm{E}_{\mathrm{df}}$ adalah penambahan energi defrost dan recoveryyang dimulai pada saat akhir Periode X (Wh).

Sedangkan temperatur rata-rata pada setiap kompartemen (Tss2-i) dihitung dengan rumus:

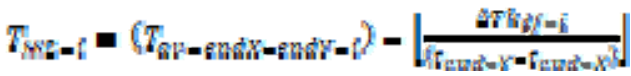

dengan:

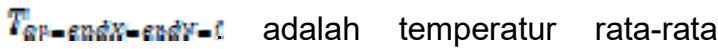
dalam kompartemen i yang terjadi selama periode kondisi stabil SS2 $\left({ }^{\circ} \mathrm{C}\right)$

$\Delta$ Sh $_{\text {if }}-i$ adalah selisih temperatur akumulasi pada kompartemen i selama periode defrost dan recovery yang dimulai pada saat akhir Periode $X$ (Kh)

\subsection{Koreksi Daya Kondisi Tunak}

Daya kondisi tunak (Pss) yang akan digunakan ada perhitungan energi lemari pendingin selanjutnya merupakan daya kondisi tunak yang didapatkan baik dengan metode SS1 maupun SS2 dan dikoreksi melalui persamaan (10). Penyesuaian ini dilakukan atas dasar pertimbangan selisih antara suhu ambient terukur selama pengujian dengan suhu ambient nominal pengujian.

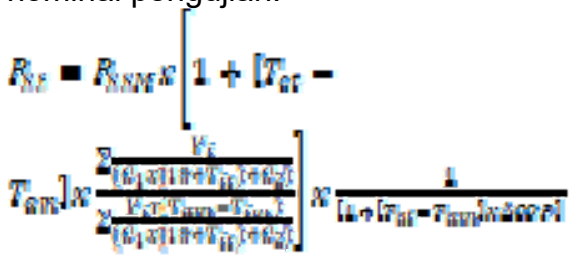

dengan:

$\mathrm{P}_{\mathrm{SSM}}$ adalah daya kondisi tunak $\mathrm{P}_{\mathrm{SS} 1}$ atau $\mathrm{P}_{\mathrm{SS} 2}$

$\mathrm{T}_{\text {at }} \quad$ adalah target temperatur ambient ruang uji

$\mathrm{T}_{\mathrm{am}}$ adalah temperatur ambient ruang uji terukur selama periode uji

$\mathrm{V}_{\mathrm{i}} \quad$ adalah volume nominal kompartemen $\mathrm{i}$

$\mathrm{T}_{\mathrm{im}}$ adalah temperatur terukur dalam kompartemen i selama periode uji

$\mathrm{T}_{\text {it }} \quad$ adalah temperatur target untuk konsumsi energi dalam kompartemen i

$\mathrm{C}_{1} \quad$ adalah nilai konstanta $=0,011364$

$\mathrm{C}_{2} \quad$ adalah nilai konstanta $=1,25$

$\triangle \mathrm{COP}$ adalah penyesuaian yang diberikan sesuai dengan jenis produk dan kondisi uji

\section{METODE PENELITIAN}

Lemari pendingin yang dijadikan sebagai benda uji dalam penelitian ini adalah lemari pendingin jenis dua pintu yang memiliki spesifikasi sebagai berikut:

Model

PR-21Seri

Tegangan

: $220 \mathrm{~V}$

Frekuensi

: $50 \mathrm{~Hz}$

Arus

$: 1,1 \mathrm{~A}$

Daya Pemanas

: $145 \mathrm{~W}$

Refrigeran

: R134a/90 g

Berat bersih

$: 41 \mathrm{Kg}$

Kelas Iklim

$: \mathrm{T}$

Volume terukur kompartemen : $41 \mathrm{~L}$

Frozen

Volume terukur kompartemen : $125 \mathrm{~L}$

Unfrozen

Set-up pengukuran dan penempatan sensor termokopel dilakukan dengan mengacu pada standar IEC 62552-1:2015 sebagaimana terlihat pada Gambar $3-5$. Sebanyak 10 sensor termokopel dipasang: 5 sensor di dalam kompartemen Frozen, 3 sensor di dalam kompartemen Unfrozen, dan 2 sensor masingmasing di sebelah kiri dan kanan dengan jarak $30 \mathrm{~cm}$ dari benda uji untuk mengukur suhu ambient. Hasil pembacaan temperatur kemudian direkam dalam suatu datalogger. Bersamaan dengan itu, pengukuran dan perekaman daya lemari pendingin dilakukan menggunakan power meter.

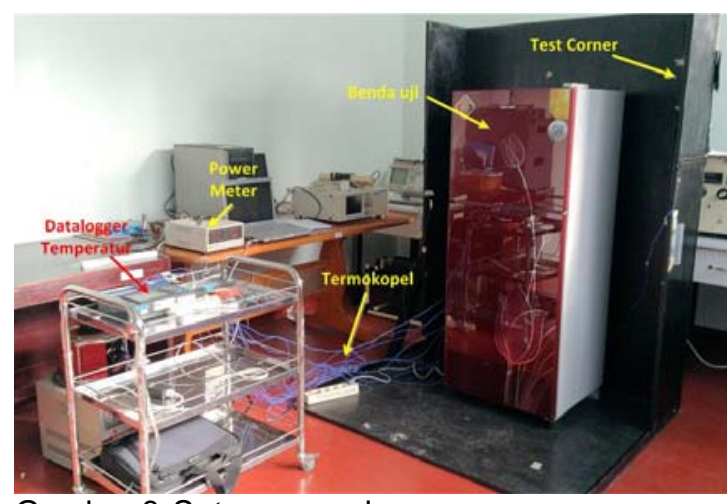

Gambar 3 Set-up pengukuran. 


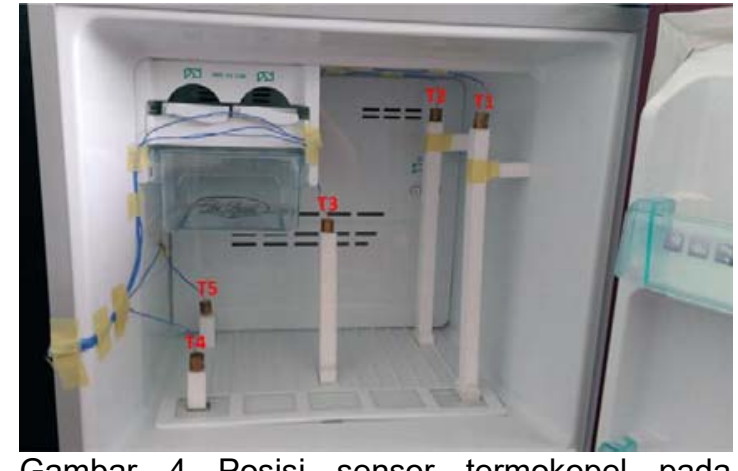

Gambar 4 Posisi sensor termokopel pada kompartemen Frozen.

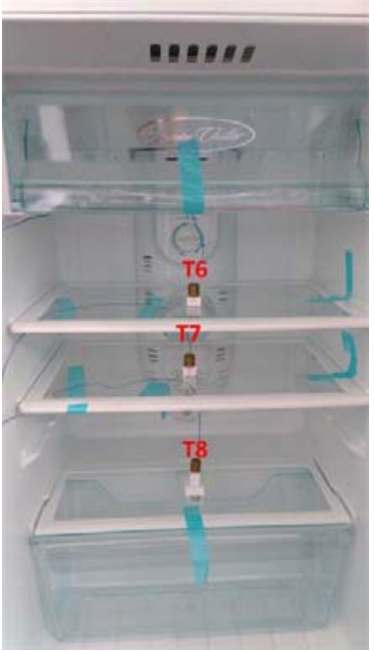

Gambar 5 Posisi sensor termokopel pada kompartemen Freshfood/Unfrozen.

Karena benda uji yang digunakan berupa lemari pendingin dengan tipe kompartemen bintang 2 (two-star), maka temperatur target untuk kompartemen frozen dan unfrozen masing-masing adalah $-12^{\circ} \mathrm{C}$ dan $4^{\circ} \mathrm{C}$. Dalam penelitian ini, pengujian dilakukan pada dua pengaturan kendali suhu yang menghasilkan dua kondisi temperatur sebagai berikut:

Tabel 1 Dua kondisi temperatur uji.

\begin{tabular}{|c|c|c|}
\hline \multirow{2}{*}{ Kondisi } & \multicolumn{2}{|c|}{ Rata-rata temp. $\left({ }^{\circ} \mathrm{C}\right)$} \\
\hline & Frozen & Unfrozen \\
\hline $\begin{array}{l}\text { Temperatur } \\
\text { bawah target (TB) }\end{array}$ & $-13,5$ & 5,9 \\
\hline $\begin{array}{l}\text { Temperatur di atas } \\
\text { target (TA) }\end{array}$ & $-9,5$ & 8,2 \\
\hline
\end{tabular}

Kondisi temperatur di atas target (TA) adalah kondisi ketika temperatur yang dicapai pada saat pengujian (khususnya untuk kompartemen frozen) lebih tinggi dari temperatur targetnya. Sedangkan kondisi temperatur di bawah target (TB) adalah kondisi yang sebaliknya.
Pengujian dilakukan pada suatu ruangan tanpa kendali suhu, dimana pengkondisi suhu ruangan dalam keadaan off untuk meminimalkan laju aliran udara di dalam ruangan. Dengan demikian, temperatur ambient yang didapatkan sesuai dengan kondisi riil ruangan pada saat pengujian berlangsung.

Perekaman data temperatur dan daya dilakukan dengan waktu logging per 10 detik. Dalam penelitian ini, pengukuran dilakukan selama 4 kali siklus defrost. Selanjutnya, pada masing-masing siklus defrost dilakukan pemeriksaan berdasarkan kriteria SS1 dan SS2 untuk menentukan daya dan temperatur kondisi tunak. Nilai daya dan temperatur kondisi tunak yang dihasilkan dari pendekatan kedua kriteria ini kemudian dibandingkan dan dianalisa.

\section{HASIL DAN PEMBAHASAN}

\subsection{Hasil Pengukuran Daya dan Suhu Kondisi Tunak pada Kondisi TB}

Gambar 6 memperlihatkan grafik temperatur dan daya yang terukur selama pengujian pada kondisi temperatur di bawah target (TB). Terjadi 4 kali defrost selama pengukuran dilakukan.

Hasil pemeriksaan kriteria kondisi tunak dengan menggunakan pendekatan SS1 bisa dilihat pada Tabel Lampiran 1. Secara keseluruhan, terdapat sebanyak 153 TCC yang dibentuk berdasarkan siklus ON-OFF kompressor. Selanjutnya dibuat blok-blok TCC ( $A$, B dan $C$ ), masing-masing blok terdiri dari 6 buah TCC sehingga persyaratan durasi minimal 2 jam dalam 1 blok terpenuhi. Baris-baris yang diberi shading(warna) pada Tabel Lampiran 1 menandakan blok-blok TCC tersebut memenuhi $\begin{array}{llllll}\text { persyaratan } & 1 & \text { sampai } & 6 & \text { kriteria } & \text { SS1 }\end{array}$ sebagaimana dijelaskan di atas. Berdasarkan persyaratan ke-7, periode uji (blok A, B dan C) terpilih adalah minimal periode ketiga yang mungkin dan memenuhi semua kriteria validitas. Oleh karena itu, dalam hal ini periode uji yang bisa dipakai sebagai kondisi tunak adalah periode uji pada blok TCC nomor 9 s.d. 26 (sebelum defrost ke-1 - DF01), nomor 48 s.d. 65 (antara defrost ke-1 dan ke-2 - DF12), dan nomor 125 s.d. 130 (antara defrost ke-3 dan ke-4 - DF34). Sedangkan pada periode antara defrost ke-2 dan ke-3 tidak ada blok TCC yang memenuhi persyaratan kondisi tunak.

Selanjutnya, nilai daya dan temperatur kondisi tunak dapat dihitung pada periode uji terpilih sebagaimana ditunjukkan hasilnya pada Tabel 2. 


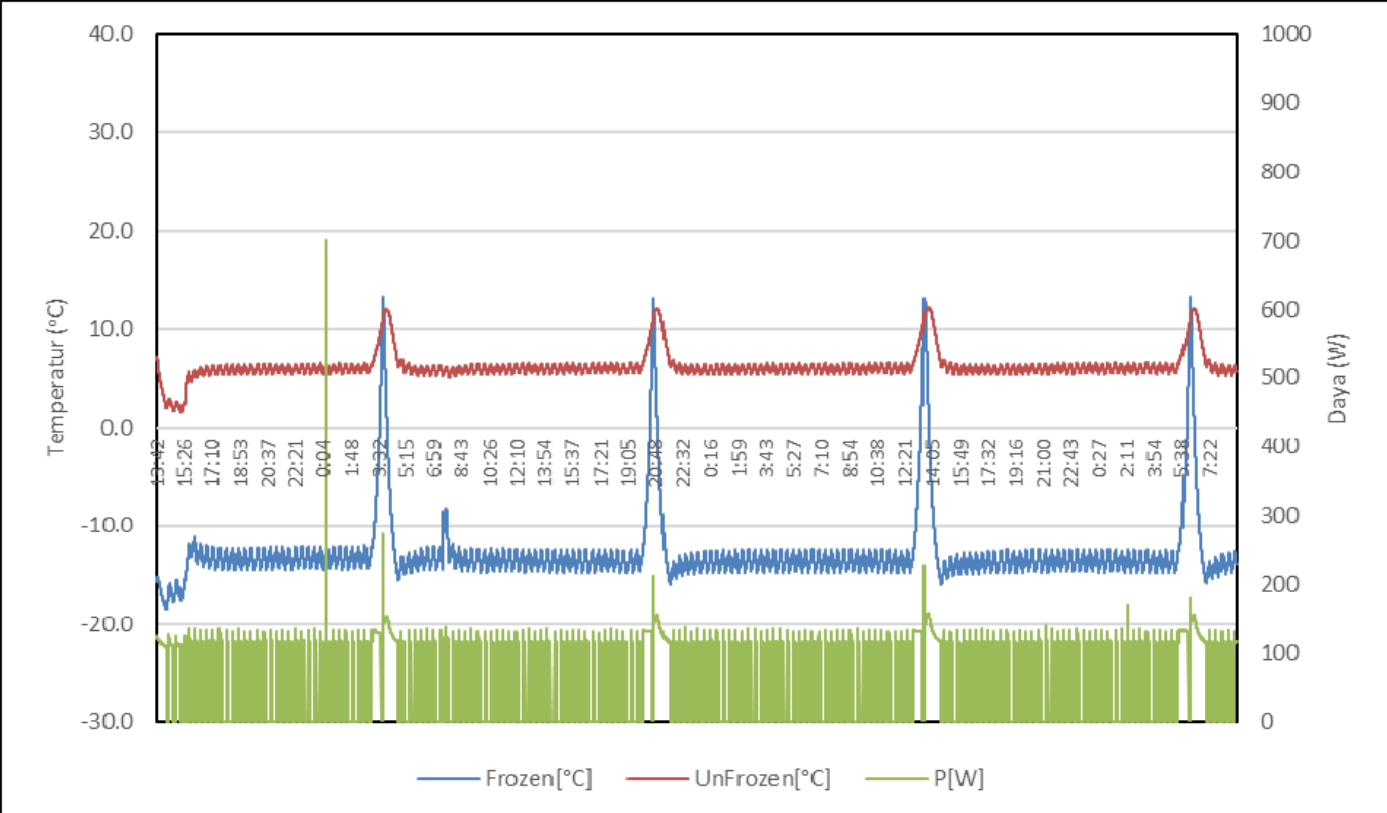

Gambar 6 Grafik temperatur dan daya lemari pendingin pada kondisi TB.

Tabel 2 Hasil perhitungan daya dan temperatur kondisi tunak (SS1) pada kondisi TB.

\begin{tabular}{ccccc} 
Periode Uji & Daya $(\mathbf{W})$ & Temp. Frozen $\left({ }^{\circ} \mathrm{C}\right)$ & Temp. Unfrozen $\left({ }^{\circ} \mathrm{C}\right)$ & Temp. Ambient $\left({ }^{\circ} \mathrm{C}\right)$ \\
\hline DF01 & 54,3 & $-13,4$ & 5,9 & 28,8 \\
DF12 & 54,4 & $-13,6$ & 5,9 & 28,9 \\
DF34 & 55,0 & $-13,6$ & 6,0 & 29,0 \\
\hline Rata-rata & 54,6 & $-13,5$ & 5,9 & 28,9 \\
\hline
\end{tabular}

Tabel 3 Pemeriksaan kriteria SS2 pada pengujian kondisi TB.

\begin{tabular}{|c|c|c|c|c|c|c|c|c|c|c|c|}
\hline \multirow[t]{2}{*}{$\begin{array}{l}\text { Siklus } \\
\text { Defrost }\end{array}$} & \multirow[t]{2}{*}{ Periode } & \multicolumn{3}{|c|}{$\begin{array}{c}\text { Rentang } \\
\text { Nomer TCC }\end{array}$} & \multirow[t]{2}{*}{$\begin{array}{c}\text { Jumlah } \\
\text { TCC }\end{array}$} & \multirow{2}{*}{$\begin{array}{c}\text { Durasi } \\
\text { jam } \\
\end{array}$} & \multirow[t]{2}{*}{$\begin{array}{l}\text { Rasio } \\
\text { durasi }\end{array}$} & \multirow{2}{*}{$\begin{array}{c}\begin{array}{c}\text { Sebaran } \\
\text { Temp. } \\
\text { Frozen }\end{array} \\
\mathrm{K} \\
\end{array}$} & \multirow{2}{*}{$\begin{array}{c}\begin{array}{c}\text { Sebaran } \\
\text { Temp. } \\
\text { Unfrozen }\end{array} \\
\mathbf{K} \\
\end{array}$} & \multirow{2}{*}{$\begin{array}{c}\begin{array}{c}\text { Sebaran } \\
\text { Daya }\end{array} \\
\% \\
\end{array}$} & \multirow{2}{*}{$\begin{array}{c}\begin{array}{c}\text { Sebaran } \\
\text { Daya }\end{array} \\
\mathbf{w}\end{array}$} \\
\hline & & & & & & & & & & & \\
\hline \multirow{2}{*}{ DF12 } & $x$ & 22 & - & 32 & 11 & 4.34 & \multirow{2}{*}{1.00} & \multirow[t]{2}{*}{0.32} & \multirow{2}{*}{0.04} & \multirow{2}{*}{$1.71 \%$} & \multirow{2}{*}{0.92} \\
\hline & Y & 61 & - & 71 & 11 & 4.34 & & & & & \\
\hline \multirow[t]{2}{*}{ DF23 } & $x$ & 61 & - & 71 & 11 & 4.34 & \multirow[t]{2}{*}{1.00} & \multirow[t]{2}{*}{0.01} & \multirow[t]{2}{*}{0.03} & \multirow[t]{2}{*}{$0.99 \%$} & \multirow[t]{2}{*}{0.54} \\
\hline & Y & 100 & - & 110 & 11 & 4.36 & & & & & \\
\hline \multirow[t]{2}{*}{ DF34 } & $x$ & 100 & - & 110 & 11 & 4.35 & \multirow[t]{2}{*}{1.00} & \multirow[t]{2}{*}{0.02} & \multirow[t]{2}{*}{0.02} & \multirow[t]{2}{*}{$0.28 \%$} & \multirow[t]{2}{*}{0.15} \\
\hline & $Y$ & 138 & - & 148 & 11 & 4.36 & & & & & \\
\hline
\end{tabular}

Tabel 4 Hasil perhitungan daya dan temperatur kondisi tunak (SS2) pada kondisi TB.

\begin{tabular}{ccccc}
\hline Periode Uji & Daya (W) & Temp. Frozen $\left({ }^{\circ} \mathrm{C}\right)$ & Temp. Unfrozen $\left({ }^{\circ} \mathrm{C}\right)$ & Temp. Ambient $\left({ }^{\circ} \mathrm{C}\right)$ \\
\hline DF12 & 54,6 & $-14,2$ & 5,7 & 28,7 \\
DF23 & 54,5 & $-14,3$ & 5,7 & 28,7 \\
DF34 & 54,6 & $-14,3$ & 5,6 & 29,0 \\
\hline Rata-rata & 54,6 & $-14,3$ & 5,7 & 28,8 \\
\hline
\end{tabular}

Hasil pemeriksaan kriteria kondisi tunak dengan menggunakan pendekatan SS2 bisa dilihat pada Tabel 3. Masing-masing periode $X$ dan $\mathrm{Y}$ yang dibentuk terdiri atas 11 TCC, sehingga persyaratan durasi minimal 4 jam bisa terpenuhi. Hasil pemeriksaan menunjukkan bahwa semua periode $\mathrm{X}$ dan $\mathrm{Y}$ antara defrost ke1 dan ke-2 (DF12), antara defrost ke-2 dan ke-3 (DF23), dan antara defrost ke-3 dan ke-4 (DF34) memenuhi persyaratan kondisi tunak dengan pendekatan SS2. Selanjutnya, nilai daya dan 
temperatur kondisi tunak dapat dihitung sebagaimana ditunjukkan hasilnya pada Tabel 4 .

\subsection{Hasil Pengukuran Daya dan Suhu Kondisi Tunak pada Kondisi TA}

Gambar 7 memperlihatkan grafik temperatur dan daya yang terukur selama pengujian dengan pengaturan kendali suhu lemari pendingin pada kondisi temperatur di atas target (TA). Terjadi 4 kali defrost selama pengukuran dilakukan, meskipun tidak terlihat secara jelas di grafik.

Hasil pemeriksaan kriteria kondisi tunak dengan menggunakan pendekatan SS1 bisa dilihat pada Tabel Lampiran 2. Terdapat sebanyak 190 TCC yang terbentuk, selanjutnya dibuat blok-blok TCC (A, B dan C) yang masingmasing blok terdiri atas 5 buah TCC. Dengan memperhatikan baris-baris yang diberi shading(warna) pada Tabel Lampiran 2, hanya ada satuperiode uji (blok $\mathrm{A}, \mathrm{B}$ dan $\mathrm{C}$ ) yang memenuhi semua kriteria kestabilan SS1, yaitu blok TCC nomor 52 s.d. 66 (antara defrost ke-1 dan ke-2 - DF12).Sedangkan blok TCC nomor 89 s.d. 103 (antara defrost ke-2 dan ke-3), tidak bisa dijadikan sebagai periode uji kondisi tunak dikarenakan 2 blok TCC sebelumnya tidak memenuhi kriteria kestabilan SS1.

Selanjutnya, nilai daya dan temperatur kondisi tunak dapat dihitung pada periode uji terpilih sebagaimana ditunjukkan hasilnya pada Tabel 5 .

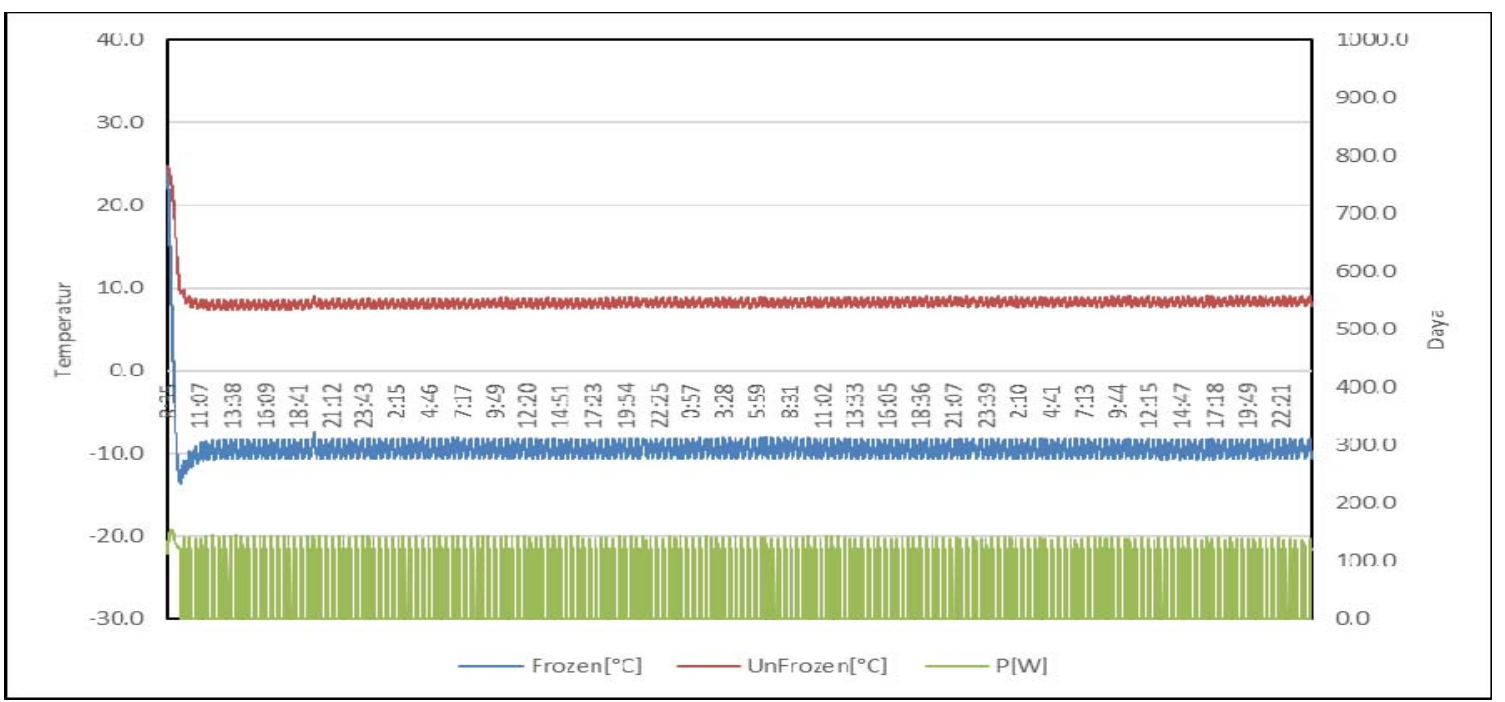

Gambar 7 Grafik temperatur dan daya lemari pendingin pada kondisi TA.

Tabel 5 Hasil perhitungan daya dan temperatur kondisi tunak (SS1) pada kondisi TA.

\begin{tabular}{ccccc}
\hline Periode Uji & Daya $(\mathrm{W})$ & Temp. Frozen $\left({ }^{\circ} \mathbf{C}\right)$ & Temp. Unfrozen $\left({ }^{\circ} \mathrm{C}\right)$ & Temp. Ambient $\left({ }^{\circ} \mathbf{C}\right)$ \\
\hline DF12 & 39,7 & $-9,5$ & 8,2 & 26,6 \\
\hline
\end{tabular}

Tabel 6 Pemeriksaan kriteria SS2 pada pengujian kondisi TA.

\begin{tabular}{|c|c|c|c|c|c|c|c|c|c|c|c|}
\hline $\begin{array}{l}\text { Siklus } \\
\text { Defrost }\end{array}$ & Periode & \multicolumn{3}{|c|}{$\begin{array}{c}\text { Rentang } \\
\text { Nomer TCC }\end{array}$} & $\begin{array}{l}\text { Jumlah } \\
\text { TCC }\end{array}$ & $\begin{array}{l}\text { Durasi } \\
\text { jam } \\
\end{array}$ & $\begin{array}{l}\text { Rasio } \\
\text { durasi }\end{array}$ & $\begin{array}{c}\text { Sebaran } \\
\text { Temp. } \\
\text { Frozen } \\
\mathbf{K} \\
\end{array}$ & $\begin{array}{c}\begin{array}{c}\text { Sebaran } \\
\text { Temp. } \\
\text { Unfrozen }\end{array} \\
\mathbf{K} \\
\end{array}$ & $\begin{array}{c}\begin{array}{c}\text { Sebaran } \\
\text { Daya }\end{array} \\
\% \\
\end{array}$ & $\begin{array}{c}\begin{array}{c}\text { Sebaran } \\
\text { Daya }\end{array} \\
\text { W } \\
\end{array}$ \\
\hline \multirow[t]{2}{*}{ DF12 } & $x$ & 14 & - & 22 & 9 & 4.09 & \multirow[t]{2}{*}{0.99} & \multirow[t]{2}{*}{0.07} & \multirow[t]{2}{*}{0.19} & \multirow[t]{2}{*}{$1.70 \%$} & \multirow[t]{2}{*}{0.66} \\
\hline & $\mathrm{Y}$ & 69 & - & 77 & 9 & 4.13 & & & & & \\
\hline \multirow[t]{2}{*}{ DF23 } & $x$ & 69 & - & 77 & 9 & 4.13 & \multirow[t]{2}{*}{1.01} & \multirow[t]{2}{*}{0.00} & \multirow[t]{2}{*}{0.14} & \multirow[t]{2}{*}{$2.52 \%$} & \multirow{2}{*}{0.98} \\
\hline & $Y$ & 124 & - & 132 & 9 & 4.08 & & & & & \\
\hline \multirow[t]{2}{*}{ DF34 } & $x$ & 124 & - & 132 & 9 & 4.08 & \multirow[t]{2}{*}{0.99} & \multirow[t]{2}{*}{0.03} & \multirow[t]{2}{*}{0.03} & \multirow[t]{2}{*}{$2.48 \%$} & \multirow[t]{2}{*}{0.97} \\
\hline & $Y$ & 179 & - & 187 & 9 & 4.11 & & & & & \\
\hline
\end{tabular}

Hasil pemeriksaan kriteria kondisi tunak dengan menggunakan pendekatan SS2 bisa dilihat pada Tabel 6 . Masing-masing periode $X$ dan $Y$ yang dibentuk terdiri atas 9 TCC. Hasil pemeriksaan menunjukkan bahwa hanya ada satu periode $X$ dan $Y$ yang memenuhi persyaratan kondisi tunak dengan pendekatan SS2, yakni antara defrost ke-1 dan ke-2 (DF12). Sedangkan antara defrost ke-2 dan ke-3 (DF23) dan antara defrost ke-3 dan ke-4 (DF34) tidak 
Analisis Penentuan Daya dan Temperatur Kondisi Tunak Pada Pengujian Konsumsi Energi Lemari Pendingin Berdasarkan IEC

62552:2015

(Nanang Kusnandar, Prayoga Bakti, Iput Kasiyanto, Qudsiyyatul Lailiyah

memenuhi persyaratan kondisi tunak, terutama untuk sebaran dayanya yang lebih dari $2 \%$. Selanjutnya, nilai daya dan temperatur kondisi tunak dapat dihitung sebagaimana ditunjukkan hasilnya pada Tabel 7 .

Tabel 7 Hasil perhitungan daya dan temperatur kondisi tunak (SS2) pada kondisi TA.

\begin{tabular}{ccccc}
\hline Periode Uji & Daya (W) & Temp. Frozen $\left({ }^{\circ} \mathrm{C}\right)$ & Temp. Unfrozen $\left({ }^{\circ} \mathrm{C}\right)$ & Temp. Ambient $\left({ }^{\circ} \mathrm{C}\right)$ \\
\hline DF12 & 39,1 & $-9,4$ & 8,1 & 26,6 \\
\hline
\end{tabular}

\subsection{Perbandingan Hasil Pengukuran Daya dan Suhu Kondisi Tunak berdasarkan Kriteria SS1 dan SS2}

Dengan membandingkan antara Tabel 2 dan Tabel 4 (kondisi TB) serta Tabel 5 dan Tabel 7 (kondisi TA), terlihat bahwa kedua pendekatan SS1 dan SS2 menghasilkan nilai daya serta temperatur kondisi tunak yang tidak jauh berbeda. Secara rata-rata, daya kondisi tunak (Pss) pada kondisi pengujian TB, baik dari pendekatan SS1 maupun SS2, adalah sebesar $54,6 \mathrm{~W}$. Sedangkan untuk temperatur, perbedaan terbesar hanya terjadi pada temperatur kondisi tunak dalam kompartemen Frozen, dengan selisih sebesar $0,8^{\circ} \mathrm{C}$.

Adapun pada kondisi pengujian TA, dimana hanya ada satu periode uji defrost yang memenuhi kriteria SS1 maupun SS2, menghasilkan daya kondisi tunak masing-masing sebesar 39,7 W dan 39,1 W, sehingga terdapat selisih sebesar 0,6 W. Namun untuk temperatur kondisi tunak, selisih terbesar yang didapat hanya sebesar $0,1^{\circ} \mathrm{C}$ pada semua kompartemen Frozen, Unfrozen, maupun ambient.

Hasil-hasil di atas menunjukkan bahwa pada dasarnya pemilihan pendekatan SS1 ataupun SS2 akan menghasilkan daya dan temperatur kondisi tunak yang relatif sama. Hanya saja, jika dilihat dari proses perhitungannya, ketika menggunakan pendekatan SS2 harus melibatkan penambahan energi defrost dan recovery $\left(\Delta \mathrm{E}_{\mathrm{df}}\right)$ dan selisih temperatur akumulasi pada kompartemen $i$ selama periode defrost dan recovery $\left(\Delta \mathrm{Th}_{\mathrm{df}-\mathrm{i}}\right)$ yang juga memiliki kriteria validitas tersendiri (DF1 atau DF2), sehingga akan memerlukan proses perhitungan yang lebih rumit dibandingkan dengan pendekatan SS1. Oleh karena itu, secara teknis, pendekatan SS2 bisa digunakan sebagai alternatif apabila kriteria kestabilan dengan pendekatan SS1 tidak terpenuhi.

Hasil di atas juga menunjukkan bahwa terdapat kondisi dimana kestabilan berdasarkan kriteria kedua pendekatan SS1 maupun SS2 tidak terpenuhi, seperti diperoleh pada siklus defrost DF23 dan DF34 kondisi pengujian TA. Jika dilihat pada hasil pemeriksaan yang ditunjukkan pada Tabel Lampiran 2 dan Tabel 6, kriteria kestabilan yang paling banyak tidak terpenuhi adalah nilai sebaran dayanya. Hal ini bisa disebabkan karena pengaruh kondisi lingkungan (temperatur ruangan) yang kurang stabil, mengingat pengujian ini dilakukan pada ruangan tanpa pengendali suhu. Oleh sebab itu, untuk mendapatkan data hasil uji yang lebih stabil, pengujian seharusnya dilakukan pada ruangan yang terkendali suhunya. Namun, standar juga menetapkan, bukan hanya temperatur ruangan yang harus terkendali, tetapi juga kecepatan angin di dalam ruangan uji yaitu tidak boleh melebihi $0,25 \mathrm{~m} / \mathrm{s}$.

\section{KESIMPULAN}

Dari hasil pengujian lemari pendingin dua pintu pada penelitian ini dapat disimpulkan bahwa penentuan daya dan temperatur kondisi tunak menggunakan pendekatan SS1 dan SS2 menghasilkan nilai yang relatif sama. Secara teknis, pendekatan SS2 bisa digunakan sebagai alternatif apabila kriteria kestabilan dengan pendekatan SS1 tidak terpenuhi.

\section{UCAPAN TERIMAKASIH}

Penulis mengucapkan puji syukur kepada Allah SWT, karena rahmat Nya penelitian ini dapat selesai. Ucapan terima kasih juga penulis sampaikan kepada P2SMTP - LIPI dan seluruh sivitas yang telah memberikan fasilitas serta bantuannya terkait penelitian ini.

\section{DAFTAR PUSTAKA}

Bansal, P., Vineyard, E., \& Abdelaziz, O. (2011). Advances in household appliances - A review. Applied Thermal Engineering 31 (2011) 3748-3760.

B2TE-BPPT. (2012). Perencanaan Efisiensi dan Elastisitas Energi 2012. Penerbit BPPT.

Cheng, W-L, Ding, M., Yuan, X-D., \& Han, B-C. (2017). Analysis of energy saving performance for household refrigerator with thermal storage of condenser and evaporator. Energy Conversion and Management 132 (2017) : 180-188. 
http://dx. doi.org/10.1016/j.enconman.2016.11.029

Chunekar, A. (2014). Standards and labeling program for refrigerators: Comparing India with others. Energy Policy, 65, 626-630. https://doi.org/10.1016/j.enpol.2013.09.069

Dwi M. \& Nanang K. (2014). Analisis Penentuan Waktu Siklus Steady State (SS) dan Defrosting (DF) pada Pengujian Kon-sumsi Daya Refrigerator Mengacu pada Standar CDV IEC 62552 2nd Edition. Prosiding AMTeQ $2014: 146$ - 161.

Geppert, J. \& Stamminger, R. (2013). Analysis of effecting factors on domestic refrigerators' energy consumption in use. Energy Conversion and Management 76 (2013) : 794-800. http://dx. doi.org/10.1016/j.enconman.2013.08.027

Hermes, CJL, \& Melo C. (2008). A first-principles simulation model for the start-up and

cycling transients of household refrigerators. International Journal of Refrigeration 2008;31:1341-1357
International Electrotechnical Commission. (2015). IEC 62552-3:2015, Household refrigerating appliances - Characteristics and test methods - Part 3: Energy Consumption and volume. Geneva, Switzerland.

Mahlia, T. M. I., \& Saidur, R. (2010). A review on test procedure, energy efficiency standards and energy labels for room air conditioners and refrigerator-freezers. Renewable and Sustainable Energy Reviews, 14(7), 18881900. https://doi.org/10.1016/j.rser.2010.03.037.

Melo, C. \& Silva, L.W.. (2010). A perspective on energy savings in household refrigerators,in: Sustainable Refrigeration and Heat Pump Technology Conference, Stockholm, Sweden.

Ouali, M., Djebiret, M.A., et al. (2016). Thermal control influence on energy efficiency in

domestic refrigerator powered by photovoltaic. International Journal of Hydrogen Energy XXX (2016) : 1-7, http://dx.doi.org/10.1016/j.ijhydene.2016.0 6.134 